\title{
EXTERNAL FACTORS OF JUVENILE DELINQUENCY AMONG STUDENTS IN THE AREA OF TRADITIONAL NIGHT CLUB
}

\author{
Niken Agus Tianingrum ${ }^{1 *}$, Sri Sunarti ${ }^{2}$ \\ ${ }^{1,2}$ Department of Public Health, Faculty of Health and Pharmacy Universitas Muhammadiyah \\ Kalimantan Timur, Indonesia \\ *E-mail : nikenagust@umkt.ac.id
}

\begin{abstract}
Nowadays, world is challenged a condition in which case the number of adolescent are bigger than before, but, this group of age are also facing the health and social problem such juvenile delinquency. External factors became the trigger factor of them, such as peer's influence and environment. This study aims to estimate the prevalence of juvenile delinquency and clearly identify external factors toward juvenile delinquency among students who live in the area of traditional night club. A cross sectional study was conducted among 369 students aged 11 to 16 years old. A total sampling was drawn from 2 Junior High Schools near Traditional Night Club in Samarinda. Data were collected using a validated questionnaire in Bahasa Indonesia. Variables measured include socio-demographic criteria, peers' and environmental influence and juvenile delinquency. Data was analyzed trough descriptive statistic and multiple linier regression. Results indicated that the prevalence of juvenile delinquency among student ages 11-16 years was high (69.7\%). This study showed that peers influence and environment contribute to juvenile delinquency. Simultaneously, peers and environment also influence juvenile delinquency $(p$-value $<0.0001)$. The result suggested the existence of school-based program for healthy adolescent as a ways to provide a better information and health community in school.
\end{abstract}

Keywords: peer, environment, juvenile delinquency, students, traditional night club

\section{INTRODUCTION}

World has been challenging a situation in which case the number of adolescent are bigger than before. Adolescent is a vulnerable group that often being exposed by delinquency behavior, such as smoking, substance abuse, risky sexual behavior, unwanted pregnancy, fights, suicide, traffic accident, missing schools and related mental health issue. In Indonesia, Global School-based Student Health Survey (GSHS) 2015 among 11,042 students reported that 23.4\% of them had a physical fight, about $1,06 \%$ of students state first consumption of drug by the age of 7 and $5,26 \%$ of students disclosed that they ever have a risky sexual behavior with their partner ${ }^{1}$.

World Health Organization (WHO) exposed a fact that more than 1.1 billion teenager aged 10-19 died in 2016, more than 3.000 died in a day and mostly caused by a preventable factors. Traffic accident become the most contributes factors in 2016. Any other factors were suicide, violence, HIV and diarrheal diseases. Some of these factors were triggered by 
juvenile delinquency ${ }^{2}$. Several factors contribute to juvenile delinquency, such as internal and external factors. Internal factor came from people's soul, but external factor came from outside person which can be called as environmental exposure ${ }^{3}$. Besides, previous study showed that juvenile delinquency also happen because of mind problem, emotional problem, religiosity, broken home and parenting pattern ${ }^{4}$.

Internal factor pushed individual to have an intention to act, but external factors build up a chance to their action, such as peer's influence and environment. Peers can influence students to act offending as well as environment, in which in this context means living environment. Students who live in a "normal" housing will be exposed by good thing and vice versa. Some of harmful environment is traditional night club (a neighborhood which provides karaoke and commercial sex service). However, study about juvenile delinquency in the area of traditional night club was very limit, despite the existence of this place going to be wider since closing prostitution area has been applied. It needs to be done a research to assess the impact of peer's influence and environment toward juvenile delinquency. This research was done to estimate the prevalence of juvenile delinquency and clearly identify external factors toward juvenile delinquency among students who live in the area of traditional night club.

\section{MATERIAL AND METHOD}

A cross sectional study was conducted among 369 students aged 11 to 16 years old. A total sampling was drawn from schools in 2 Junior High Schools near Traditional Night Club in Samarinda, Indonesia, where all students were invited to participate. Data were collected using a self-administered, pretested and validated questionnaire in Bahasa Indonesia. Variables measured include socio-demographic criteria, peers' and environmental influence and juvenile delinquency. Peer's influence was measured using a questionnaire with four Likert scale options (10 questions) and environment was measured with two options questions (6 questions). For each peer influence and environment, the total score will be calculated. Juvenile delinquency were measured by two options questions (Yes and No) about smoking, substance abuse, risky sexual behavior, unwanted pregnancy, fights, traffic accident, watching porn, missing schools and thieving. Data was analyzed trough descriptive statistic and multiple linier regression. All respondents provided written informed consent. This study was approved by Ethical Committee of Mulawarman University with the reference number of 75/KEPK-FK/VI/2019.

\section{RESULTS AND DISCUSSION}

Traditional night club was a place of neighborhood which provide a karaoke service and practice of engaging sexual activity in exchange of instant payment in money or others. It called traditional because it settled in civilian housing. This place is not only as a traditional night club, but also a place for residential area. So, the practice of hidden prostitution and human living were blended. 
A total of 369 questionnaires were delivered; of which, 337 were gathered $(91.33 \%$ respond rate). Results indicated that the prevalence of juvenile delinquency among student ages $11-16$ years was high $(69.7 \%)$.

Table 1. Respondents' Distribution based on Juvenile Delinquency

\begin{tabular}{cccc}
\hline Category & \multicolumn{2}{c}{ Total } & \\
\cline { 2 - 2 } & $\mathrm{N}$ & & $\%$ \\
& 102 & & 30,3 \\
No Delinquency & 235 & & 69,7 \\
Delinquency & $\mathbf{3 3 7}$ & & $\mathbf{1 0 0}$ \\
\hline Total & &
\end{tabular}

The biggest delinquency behavior among students is watching porn (34.4\%), fights (30.9\%), missing schools (28.8\%) and smoking (27.6\%). Below is the prevalence of juvenile delinquency based on type of delinquency.

Juvenile delinquency behavior was going to be huge, because of more than half teenager show their delinquency. Most teenager and even under age were contacted with social problem, such as smoking, drugs, free sex, violence, thieving and many involvement in crime ${ }^{5}$. Previous study showed that juvenile delinquency is a common behavior among teenager and social environment gave the stimulus toward it $^{6}$. This study revealed that mostly student's misbehavior were watching porn, violence, truant and smoking. This behavior can be triggered by peers and also their environment which nearby traditional night club.

Table 2. Prevalence of Juvenile Delinquency among Respondents

\begin{tabular}{lcccr}
\hline \multirow{2}{*}{ Type of Delinquent Behaviour } & \multicolumn{3}{c}{$\mathbf{N}$} \\
\cline { 2 - 5 } & $\mathbf{N o}$ & $\mathbf{\%}$ & $\mathbf{Y e s}$ & $\mathbf{\%}$ \\
\hline Violence & 233 & 69.1 & 104 & 30.9 \\
Glue inhalation & 327 & 97.0 & 10 & 3.0 \\
Street race & 293 & 86.9 & 44 & 13.1 \\
Kissing & 331 & 98.2 & 6 & 1.8 \\
Petting & 334 & 99.1 & 3 & 0.9 \\
Intercourse & 334 & 99.1 & 3 & 0.9 \\
Alcohol use & 324 & 96.1 & 13 & 3.9 \\
Substance abuse & 331 & 98.2 & 6 & 1.8 \\
Thieving & 267 & 79.2 & 70 & 20.8 \\
Watching porn & 221 & 65.6 & 116 & 34.4 \\
Truant & 240 & 71.2 & 97 & 28.8 \\
Smoking & 244 & 72.4 & 93 & 27.6 \\
\hline
\end{tabular}

Peer influence show the mean score is 15.69 with minimum score is 10 and maximum 31 . As for environmental influence shows the mean score is 0.83 with minimum score is 0 and maximum score is 6 . 
Table 3. Statistical analysis of external factors toward juvenile delinquency

\begin{tabular}{lccc}
\hline \multicolumn{1}{c}{ External Factors } & $\begin{array}{c}\text { Coef. } \\
\text { Regression }\end{array}$ & T & p-value \\
\hline Konstanta & 0.608 & & \\
X1 (Environmental factor) & 0.931 & 12.803 & $<0.0001$ \\
X2 (Peer factor) & 0.039 & 2.065 & 0.04 \\
\hline $\mathrm{F}=94.288$ & & & $<0.0001$ \\
R-Square $=0.362$ & & & \\
\hline
\end{tabular}

This study revealed that peers influence and environment contribute to juvenile delinquency. Partially, there is significant influence between peers ( $p$-value $=0.04$ ) and environment $(p-v a l u e<0.0001)$ toward juvenile delinquency. Simultaneously, peers and environment also influence juvenile delinquency ( $\mathrm{p}$-value $<0.0001$ ) with $\mathrm{R}$ square $36.2 \%$, which is mean delinquency behavior can be explained by peers influence and environment in the amount of $36.2 \%$.

Peers become crucial human environment which can become a role and leader for teenager to behave. Researchers have already identified that peers played a key role in delinquency and criminalities ${ }^{7}$. Sense of friendship became greater among teenager. However, this feeling can lead a person to follow their friends without thinking about the impact of their behavior ${ }^{8}$. Several studies also conclude that juvenile delinquency was predisposed prominently by their peers ${ }^{9,10}$.

Besides, environmental condition also contributes to form their delinquency behavior. This research exposed that environment also influence the juvenile delinquency. This finding discovered a factor from social live that unmet need with teenager's prerequisites for living. The residential place near prostitution area will have an impact to adolescent and around it ${ }^{11}$. Then, family enhanced the main factor to form their behavior because it was the first place to build up their character ${ }^{12}$. Also, parenting pattern were important to give the education to behave in society ${ }^{13}$.

\section{CONCLUSION}

This study concludes that peers and environment influence juvenile delinquency. Student as adolescent who spent the most their time in school will involve them into vulnerable circumstances if they are exposed by bad peers and environment. This finding is pertinent because more than one third factors influence juvenile delinquent is peers and environment (36.2\%). Schools have the responsible to build student's attitude and behavior, and construct healthy peer as well. This research found that schools in this area have not any involvement to health project yet such as peer educator. In Indonesia, especially Samarinda, Traditional Night Club became a low-middle recreation place for local people, so it is placed near a village, and in this case, coincidentally near schools. It also provides a tool to form the behavior. Furthermore, it will affect students to pass the area every day, meet the worker and interact with society as well. Even, some of the students also become a resident in there. The result suggested the existence of school-based program for healthy adolescent as a ways to 
provide a better information and health community in school. It can be conducted by coordination and cooperation with nearest Primary Health Care. It is also needed an effort to prevent adolescent from damage of Traditional Night Club's exposure, such as enhancing and strengthening adolescent attitude about reproductive health, juvenile delinquency and related issue through community development.

\section{REFERENCES}

${ }^{1}$ Kusumawardhani, Nunik, dkk. Perilaku Berisiko Kesehatan pada Pelajar SMP dan SMA di Indonesia (Hasil Survei Nasional Kesehatan Berbasis Sekolah di Indonesia). Puslitbang Upaya Kesehatan Masyarakat Balitbangkes Kementerian Kesehatan RI .2015

2 WHO. Adolescent: Health Risk and Solution; 2019 [Cited 2019] Available from: www.who.int/en/news-room/fact-sheets/detail/adolescents-health-risks-and-solutions

${ }^{3}$ Yusuf, A., Tristiana, R. D., \& Agustina, N. Gambaran Spiritualitas Remaja yang Tinggal di Sekitar Eks-lokalisasi. 2018

${ }^{4}$ Yuniati Ani, Suyahmo \& Juhadi. Perilaku Menyimpang dan Perilaku Kekerasan Siswa SMP di Kota Pekalongan. Journal of Educational Social Studies. 2017; 1: 1-6

5 Shidiq, Alima Fikri \& Raharjo, Santoso Tri.(2018). Peran Pendidikan Karakter di Masa Remaja sebagai Pencegahan Kenakalan Remaja.2018; 5 (2):176-187.

${ }^{6}$ Unayah, Nunung \& Sabarisman, Nina. Fenomena Kenakalan Remaja dan Kriminalitas. $2015 ; 1(2)$

${ }^{7}$ Walters, G. D. Peer influence or projection bias? Predicting respondent delinquency with perceptual measures of peer delinquency in 22 samples. Journal of Adolescence. 2018; 1:112

${ }^{8}$ Sigalingging, Ganda \& Sianturi, Ira Ardany. Hubungan Teman Sebaya dengan Perilaku Seksual Remaja Di SMK Medan Area Medan Sunggal. Jurnal Darma Agung Husada. 2019; 5(1):9-15.

${ }^{9}$ Fitriani, Wihelmina \& Hastuti, Dwi. Pengaruh Kelekatan Remaja dengan Ibu, Ayah, dan Teman Sebaya terhadap Kenakalan Remaja di Lembaga Pembinaan Khusus Anak (LPKA) Kelas II Bandung.2016;9(3).

${ }^{10}$ Hidayati, Novi Wahyu. Hubungan Harga Diri dan Konformitas Teman Sebaya dengan Kenakalan Remaja. Jurnal Penelitian Pendidikan Indonesia (JPPI); 2016;1(2). 
Received :2019-12-04 Revised : 2020-01-24 Acceptance : 2020-04-27 Publish : 2020-06-05

${ }^{11}$ Kondangwongko, N. Faktor yang Mempengaruhi Tingkat Kenakalan Remaja. Jurnal Logos Spectrum. 2012; 7(4)

${ }^{12}$ Hussainant M., Al-Maltaka F. Juvenile Delinquency and Family envirinmentIn Jordan. Journal of Sociological Research. 2012; 3(2):599-617

13 Tapia BM, Alarid LF and Clare C. Parenting Styles and Juvenile Delinquency: Exploring Gendered Relationships.2018; 2:21-36 